\title{
Analysis of SeaWiFS Imagery over the Southwestern Atlantic Ocean during the March 2002 R/V IOFFE Cruise
}

\author{
Frederico de Moraes Rudorff $\mathrm{a}^{\mathrm{a}}$ and the NF-POGO Ocean-Color Training Group ${ }^{1}$, Robert J. Frouin ${ }^{\mathrm{b}}$, \\ Milton Kampel $^{\mathrm{a}}$, Oleg Kopelevich ${ }^{\mathrm{c}}$, Vivian Lutz ${ }^{\mathrm{d}}$ \\ anstituto Nacional de Pesquisas Espaciais, PO Box 515, 12201-970, São José dos Campos, Brazil; \\ ${ }^{\mathrm{b}}$ Scripps Institution of Oceanography, San Diego, 9500 Gilman Drive, La Jolla, CA 92093-0224; \\ ${ }^{c}$ P. P. Shirshov Institute of Oceanology, 36 Nakhimovsky Prospect, 117851, Moscow, Russia; \\ ${ }^{\mathrm{d} I n s t i t u t o}$ Nacional de Investigacion y Desarrollo Pesquero, Paseo Victoria Ocampo 1, 7600 Mar del \\ Plata, Argentina.
}

\begin{abstract}
SeaWiFS ocean-colour products for the Southwestern Atlantic Ocean are evaluated in comparison with in situ bio-optical data collected during the March 10-12, 2002 cruise from Ushuaia to Uruguay. Radiometric measurements and surface water sampling were carried out at 14 stations. The in situ dataset included HPLC chlorophyll- $a$ concentration (chl- $a$ ), $\mathrm{a}_{\mathrm{ph}}(\lambda)$ spectral absorption coefficients of phytoplankton, suspended particles, and $\mathrm{a}_{\mathrm{cdom}}(\lambda)$ dissolved organic matter, $\mathrm{R}_{\mathrm{RS}}$ remote sensing reflectance, AOT and aerosol optical thickness. In general, the SeaWiFS-derived and SIMBAD measured AOT were low, but with a good agreement within SIMBAD uncertainty errors. The SeaWiFS-derived $R_{R S}$ was systematically underestimated, but still with good fits. The $a_{p h}^{*}(440)$ were high indicating the presence of small size cells with a low packaging effect. The HPLC pigment composition did not show strong variations amongst the sampled points, with communities most probably dominated by small cells. The phytoplankton community was more homogeneous in the southern stations, than in the northernmost stations influenced by the mixing of the Brazil and Malvinas Currents and the La Plata River discharge. The analyzes of the in situ $\mathrm{a}_{\text {cdom }}(440)$ characterized the sampling stations as CDOM rich waters. All SeaWiFS chl- $a$ algorithms showed reasonable performances. The empirical algorithms overestimated lower chl- $a$ while underestimated higher concentrations. The GSM01 semi-analytical algorithm underestimated most chl- $a$ values, while CARDER underestimated only the lower concentrations. It is expected that the accuracy of chlorophyll retrievals in coastal areas of the BMC can be improved by a proper tuning of the semi-analytical models with regional inherent optical properties measurements.
\end{abstract}

Keywords: Ocean-color algorithms, atmospheric and ocean optics, SIMBAD, phytoplankton, dissolved organic matter, radiometric measurements, Southwestern Atlantic Ocean.

\section{INTRODUCTION}

The Sea-viewing Wide Field-of-view Sensor (SeaWiFS) has been providing ocean-color image products to the scientific community since September 1997. These products have been used in a broad range of scientific investigations, such as spatial and temporal variability of chlorophyll- $a$ concentration (chl-a) (Holm-Hansen et al. 2004), phytoplankton

*fmr@dsr.inpe.br; phone 5512 39456477; fax 5512 39456488; inpe.br

\footnotetext{
${ }^{1}$ The NF-POGO Ocean-Color Training Group: Adriana G. Gonzalez-Silvera ${ }^{\mathrm{e}}$, Ana I. Dogliotti ${ }^{\mathrm{f}}$, Cesar F.Garcia-Llano ${ }^{\mathrm{g}}$, Eduardo Santamaría-del-Angel ${ }^{\mathrm{e}}$, Eduardo N. de Oliveira ${ }^{\mathrm{h}}$, Eduardo M. de Souza ${ }^{\mathrm{i}}$, Ezzat S. Chalhoub ${ }^{\mathrm{a}}$, Marcio S. de Souza ${ }^{\mathrm{j}}$, Mauricio A. Noernberg $^{\mathrm{k}}$, Mayza Pompeu ${ }^{\mathrm{i}}$, Melissa Carvalho ${ }^{\mathrm{i}}$, René Ayala ${ }^{1}$, and Sergio Cerdeira ${ }^{\mathrm{m}}$.

${ }^{\mathrm{e}}$ Universidad Autónoma de Baja California, Mexico; ${ }^{\mathrm{f}}$ Institute of Astronomy and Space Physics, Argentina; ${ }^{\mathrm{g}}$ Universidad del Magdalena, Colombia; ${ }^{\mathrm{h}}$ Universidade Federal Fluminense, Brazil; ${ }^{\mathrm{i} U n i v e r s i d a d e ~ d e ~ S a ̃ o ~ P a u l o, ~ B r a z i l ; ~}{ }^{\mathrm{j}}$ Fundação Universidade Federal do Rio Grande, Brazil; ' ${ }^{\mathrm{K}}$ Universidade Federal do Paraná, Brazil; ${ }^{1}$ Universidad Simón Bolívar, Venezuela; ${ }^{\mathrm{m}}$ Comissón Nacional para el Conocimiento y Uso de la Biodiversidad, Mexico.
}

Coastal Ocean Remote Sensing, edited by Robert J. Frouin, ZhongPing Lee, Proc. of SPIE Vol. 6680, 668016, (2007) · 0277-786X/07/\$18 · doi: 10.1117/12.739472 
primary production (Behrenfeld et al. 2001; Joint and Groom, 2000), inherent optical properties (Hoge and Lyon, 2005), and colored dissolved organic matter (CDOM) (Siegel et al. 2000), amongst others.

Even though extensive scientific results have been obtained using SeaWiFS-derived products, it is important to understand the potentials and limitations of these products. SeaWiFS was the first ocean color mission to use an extensive post-launch vicarious calibration (Eplee et al. 2001) in order to minimize uncertainties due to sensor

calibration and radiative transfer modeling of atmospheric processes (Méling et al. 2001). Nevertheless, atmospheric correction is still a matter of concern in ocean color remote sensing, since only about $10 \%$ of the signal that reaches the sensor is from the ocean, the remaining $90 \%$ originating from the atmosphere and surface.

Since the launch of the Coastal Zone Color Scanner (CZCS) on 1978, much effort have been applied to estimate chl- $a$ based on empirical relationships between remote sensing reflectance $\left(\mathrm{R}_{\mathrm{RS}}\right)$ or equivalent normalized water- leaving radiance ratios and in situ chl- $a$ (Maritorena et al. 2002). These algorithms perform relatively well in Case I waters where other optically active constituents co-varies with phytoplankton. However, in more complex coastal waters this usually is not the case. Both CDOM and phytoplankton absorb at blue wavelengths and therefore the empirical algorithms have a tendency to overestimate chl- $a$ in Case II waters (Carder et al, 2004).

More complex semi-analytical algorithms have been developed based on optical closure relationships. These models relate the $R_{R S}$ or the normalized water-leaving radiance spectra to inherent optical properties of seawater, such as the backscattering coefficient, $b_{b}(\lambda)$, and absorption coefficients of water, $a_{w}(\lambda)$, phytoplankton, $a_{\text {ph }}(\lambda)$, and CDOM, $a_{\text {cdom }}(\lambda)$ (Maritorena et al. 2002). An advantage of these algorithms is that they attempt to model the bio-optics of ocean color, and by providing simultaneously several parameters of the inherent optical properties they can estimate more accurately chl-a (Maritorena et al. 2002).

This study aims to verify the accuracy of SeaWiFS-derived products, namely AOT, $\mathrm{R}_{\mathrm{RS}}$, chl- $a$, $\mathrm{a}_{\mathrm{ph}}(\lambda)$, and $\mathrm{a}_{\text {cdom }}(\lambda)$, estimated by different empirical and semi-analytical algorithms using a bio-optical dataset collected during the March 10-12, 2002 R/V IOFFE cruise from Ushuaia, Argentina to Montevideo, Uruguay.

\section{MATERIAL AND METHODS}

\subsection{Study Area}

The Argentinean Patagonian shelf situated on the Subtropical Convergence is a very dynamic zone influenced by the complex interaction of tides, the Confluence of the Brazil (BC) and Malvinas Currents (MC), and shelf water of various origins $^{1,2}$. The Brazil-Malvinas Confluence (BMC) is formed by the collision between the MC flowing northward and the $\mathrm{BC}$ flowing southward. The $\mathrm{MC}$ is formed by relatively fresh, nutrient rich and cold waters, while the $\mathrm{BC}$ is formed by warmer and relatively poor waters. At the confluence zone, a complex mesoscale oceanic circulation is associated with intense mixing of water masses forming a sharp temperature discontinuity filled with warm and cold core eddies, filaments and meanders. The BMC moves southward during the Austral summer and northward during the winter.

\subsection{In situ bio-optical data}

The in situ bio-optical data were collected during the R/V Akademik Ioffe cruise in the Southwestern Atlantic Ocean between March $10^{\text {th }}$ and $12^{\text {th }}$ of 2002. Above-water radiometric measurements were taken and surface water was collected to determine chl- $a$ and specific absorption coefficients, as described bellow.

\subsubsection{Radiometric measurements}

The radiometric measurements were carried out with a SIMBAD radiometer ${ }^{3}$. With this handheld above-water radiometer basic ocean-color variables were obtained, namely aerosol optical thickness, AOT, and remote sensing reflectance, $R_{R S}$, in five spectral bands centered at $443,490,560,670$, and $870 \mathrm{~nm}$. 
The measurements and data processing were performed according to specific protocols. The AOT was obtained by viewing the sun disk, and by measuring the direct atmospheric transmittance. Marine reflectance was obtained by viewing the ocean surface and measuring the upwelling radiance through a vertical polarizer at $45^{\circ}$ from nadir (near the Brewster angle), and at $135^{\circ}$ in azimuth from the Sun's principal plane. This viewing geometry minimizes the effects of reflected sky radiation and sun glint ${ }^{3}$.

\subsubsection{Analysis of water samples}

Surface water samples were taken in accordance to Mitchell et al. ${ }^{4}$ and Bidigare and Trees ${ }^{5}$ protocols. Samples for pigment analysis by HPLC were filtered just after collection through Whatman $25 \mathrm{~mm}$ GF/F glass fiber filters with 0.7 $\mu \mathrm{m}$ average retention capacity, and stored in liquid nitrogen. The filtration volume varied from around $1 \mathrm{~L}$ in eutrophic waters to $5 \mathrm{~L}$ in oligotrophic areas.

The spectral absorption coefficients, i.e., $a_{s}(\lambda), a_{p h}(\lambda)$, and $a_{\text {cdom }}(\lambda)$ were measured onboard the ship with a Cary-50 Spectrophotometer ${ }^{4}$. Surface water samples were classified using the water optical classification of Prieur and Sathyendranath ${ }^{6}$, according to the relative contributions of the $\mathrm{a}_{\mathrm{s}}, \mathrm{a}_{\mathrm{ph}}$, and $\mathrm{a}_{\mathrm{cdom}}$ at $440 \mathrm{~nm}$.

\subsection{SeaWiFS imagery}

SeaWiFS Level 1 images were obtained from the NASA's Ocean Color Web Site covering the study area and the sampling period. The Level 1 images were processed to Level 2 using the msl12 routine on the SEADAS 4.9 software. The derived products were: empirical OC4v4 chl- $a^{7}$, semi-analytical chl- $a$ using CARDER $^{8,9}$, and Garver, Siegel and Maritorena (GSM01) ${ }^{10}$ algorithms; $\mathrm{a}_{\mathrm{ph}}(\lambda)$ and $\mathrm{a}_{\mathrm{cdom}}(\lambda)$, estimated by the CARDER and GSM01 algorithms and by the quasi-analytical algorithm (QAA) ${ }^{11}$; aerosol optical thickness (AOT); and $\mathrm{R}_{\mathrm{RS}}$.

\subsection{Match-up analysis}

A window of $3 \times 3$ pixels was used to extract the values of each image parameter for the corresponding in situ station. Basic descriptive statistical parameters were then calculated for each box considering only the non flagged valid pixels. The performance of the SeaWiFS products was assessed by regressing satellite estimates and in situ measurements. The linear transformed root-mean-squared error (rmse-L) ${ }^{9}$, the mean relative percentage difference (RDP), and the mean absolute percentage difference (ADP) ${ }^{10}$ were calculated as follows:

$$
\begin{aligned}
\text { rmse } & =\sqrt{\frac{1}{N} \sum_{i=1}^{N}\left[\log _{10}\left(\frac{\text { Sat }}{\text { insitu }}\right)^{2}\right]} \\
r m s e-L & =0,5\left[\left(10^{+r m s e}-1\right)+\left(1-10^{-r m s e}\right)\right] \\
R D P & =\sum_{n=1}^{N}\left(\frac{\text { Sat }- \text { insitu }}{\text { insitu }}\right) \frac{1}{N} \times 100 \% \\
A D P & =\sum_{n=1}^{N}\left|\frac{\text { Sat }- \text { insitu }}{\text { insitu }}\right| \frac{1}{N} \times 100 \%
\end{aligned}
$$

where Sat denotes the satellite parameter and insitu the reference measurement. 


\section{RESULTS AND DISCUSSION}

The spatial variability of chl- $a$ over the study area can be visualized on the eight-day binned SeaWiFS image from March $6^{\text {th }}$ to $13^{\text {th }}$ of 2001 (Figure 1). The cold nutrient rich waters of the MC are evidenced over slope and shelf waters by the green, yellow and red tonalities. Over the slope the MC presented chl- $a$ between 0.2-0.9 mgm ${ }^{-3}$, while in the inner shelf the values varied from 0.2 to $2.5 \mathrm{mgm}^{-3}$. These higher chl- $a$ in the inner shelf can be associated to the shelf fronts created by strong vertical mixing that is promoted by very energetic tidal currents in the region ${ }^{13,14}$. An interesting coccolithophore bloom is evidenced along the Patagonian shelf break in red color, with chl- $a$ between $4-7 \mathrm{mgm}^{-3}$. According to the literature ${ }^{15}$, similar blooms usually starts after the nutrient depletion of the austral spring diatom dominated bloom in November, having a peak in January and ending at the end of March. In January the chl-a climatology along the shelf break is $2.19 \mathrm{mgm}^{-3}$, while in March, this value is $1.03 \mathrm{mgm}^{-3}$. Therefore, the values showed on the eight-day binned chl- $a$ image (Figure 1) correspond to a high positive anomaly. The SeaWiFS chl- $a$ estimates associated with the La Plata River mouth are even much higher, with values above $10 \mathrm{mgm}^{-3}$. Northeastwards from the La Plata River, lower chl- $a$ values $\left(<0.2 \mathrm{mgm}^{-3}\right)$ are associated with the oligotrophic waters of the Brazil Current, shown in blue tonalities.

The in situ HPLC chl- $a$ varied between $0.27-0.87 \mathrm{mgm}^{-3}$, with a mean value of $0.48( \pm 0.23) \mathrm{mgm}^{-3}$. These values were relatively higher on the southernmost stations sampled on March $10^{\text {th }}$. As can be seen on Figure 1, these southern stations are localized over the nutrient rich waters of the MC with a mean chl- $a$ of $0.77 \pm 0.09 \mathrm{mgm}^{-3}$. The stations collected on March $11^{\text {th }}$ are situated further north, just outside the shelf break, with a mean value of $0.31( \pm 0.03) \mathrm{mgm}^{-3}$. The northernmost stations collected on March $12^{\text {th }}$ are between the La Plata River mouth and the algal bloom on the shelf break. These stations are closer to the BC, with chl- $a$ mean value of $0.33( \pm 0.06) \mathrm{mgm}^{-3}$.

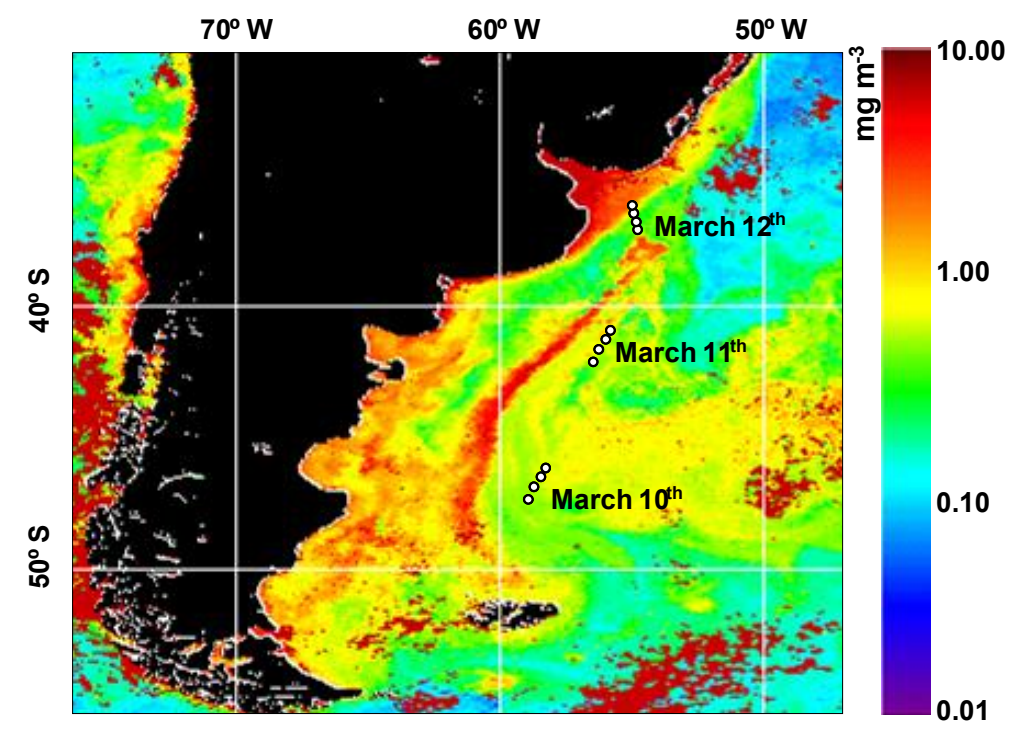

Fig. 1. Eight-day binned SeaWiFS chl- $a$ image from March $6^{\text {th }}$ to $13^{\text {th }} 2002$ and the localization of the in situ stations in the Brazil-Malvinas Confluence zone. Chl- $a$ values are on a logarithmic scale. Blue tones $\left(<0.2 \mathrm{mgm}^{-3}\right)$ are associated with the Brazil Current. Yellow-greenish tones with higher values are associated with the Malvinas Current (see text).

\subsection{SeaWiFS versus SIMBAD}

The AOT measured by both SIMBAD and SeaWiFS were very low during the campaign with values bellow 0.045 (Figure 2). In general, SeaWiFS overestimated the SIMBAD AOT, with discrepancies more evident on March $12^{\text {th }}$ at 560 and $670 \mathrm{~nm}$. But there is still good agreement between the two types of estimates within SIMBAD uncertainty errors. (rmse-L $<0.25$, see Table 1$)$. 

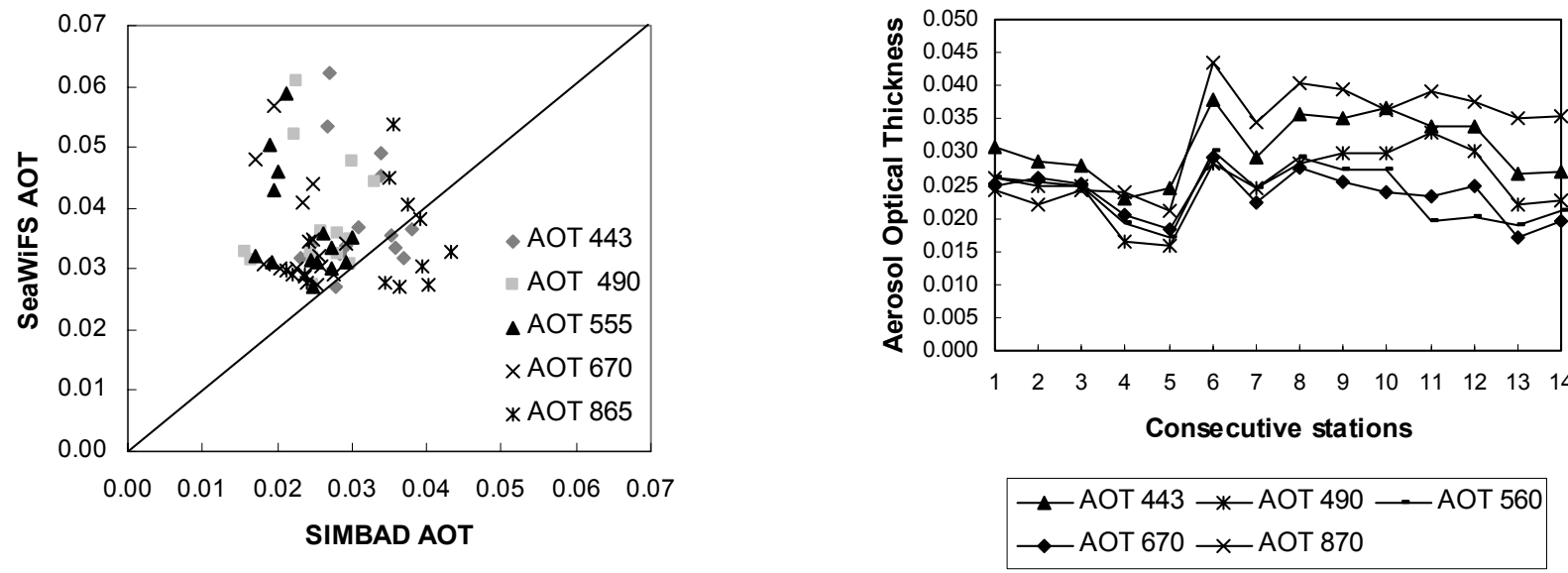

Fig. 2. (a) Comparisons between in situ AOT and SeaWiFS AOT for different spectral bands. (b) Behavior of the in situ AOT along the consecutive stations measured by SIMBAD for the different bands.

Table 1. SeaWiFS performance for AOT retrieval, with respect to SIMBAD data.

\begin{tabular}{ccccccc}
\hline $\mathbf{n m}$ & rmse-L & RDP & ADP & $\mathbf{r}^{2}$ & Slope & Intercept \\
\hline $\mathbf{4 4 3}$ & 0.15 & 0.50 & 35.68 & 0.01 & 0.04 & -0.19 \\
$\mathbf{4 9 0}$ & 0.21 & 0.70 & 54.81 & 0.00 & 0.03 & 0.12 \\
$\mathbf{5 5 5}$ & 0.24 & 0.79 & 63.85 & 0.20 & 0.06 & -0.99 \\
$\mathbf{6 7 0}$ & 0.22 & 0.73 & 57.81 & 0.20 & 0.06 & -1.10 \\
$\mathbf{8 7 0}$ & 0.12 & 0.40 & 8.13 & 0.07 & 0.03 & 0.27 \\
\hline
\end{tabular}

Comparisons of SeaWiFS-derived and SIMBAD measured $\mathrm{R}_{\mathrm{RS}}$ showed high coefficients of determination (Table 2). The $\mathrm{R}_{\mathrm{RS}}(490)$ presented the best fit $\left(\mathrm{r}^{2} 0.93\right)$, while the $\mathrm{R}_{\mathrm{RS}}(443)$ presented the lowest fit $\left(\mathrm{r}^{2} 0.86\right)$. But in general, the SeaWiFS-derived $R_{R S}$ was systematically underestimated (Figure 3). One plausible explanation for this discrepancy could be the overestimation of AOT, as shown previously (Figure 2).

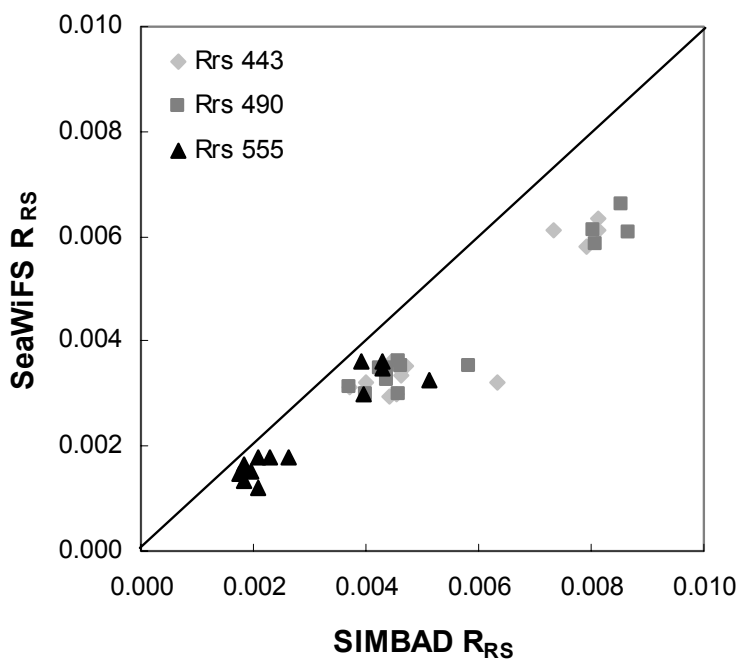

Fig. 3. Plot of in situ SIMBAD $\mathrm{R}_{\mathrm{RS}}$ versus orbital SeaWiFS $\mathrm{R}_{\mathrm{RS}}$. 
Table 2. SeaWiFS performance for $\mathrm{R}_{\mathrm{RS}}$ retrieval, with respect to SIMBAD data.

\begin{tabular}{ccccccc}
\hline $\mathbf{R}_{\mathbf{R S}}(\mathbf{n m})$ & rmse-L & RDP & ADP & $\mathbf{r}^{\mathbf{2}}$ & Slope & Intercept \\
\hline $\mathbf{4 4 3}$ & 0.50 & -26.61 & 26.61 & 0.86 & 0.64 & 0.0005 \\
$\mathbf{4 9 0}$ & 0.47 & -26.14 & 26.14 & 0.93 & 0.62 & 0.0006 \\
$\mathbf{5 5 5}$ & 0.41 & -21.57 & 21.57 & 0.89 & 0.73 & 0.0001 \\
\hline
\end{tabular}

\subsection{SeaWiFS versus in situ bio-optics}

The in situ absorption coefficients revealed that the waters sampled in the BMC were optically complex. The CDOM presented a mean relative contribution of $51 \%( \pm 17 \%)$ to total absorption, while the phytoplankton contribution was $41 \%$ $( \pm 16 \%)$. The suspended particulate material had a very low contribution, with a mean value of $8 \%( \pm 3 \%)$. Thus, the waters collected can be optically classified as Case II waters dominated by CDOM and chlorophyll absorption, according to the classification of Prieur and Sathyendranath ${ }^{6}$.

The values of the specific absorption coefficient of phytoplankton, i.e., absorption normalized by chl- $a, a_{p h}^{*}(440)$, were high, ranging between $0.05-0.11 \mathrm{~m}^{-2} \mathrm{mg}^{-1} \mathrm{chl}-a$ (average $0.08 \mathrm{~m}^{-2} \mathrm{mg}^{-1}$ ), indicating the presence of small size cells with a low packaging effect ${ }^{9}$. The values of $a_{p h}^{*}(440)$ for the $10^{\text {th }}$ and $11^{\text {th }}$ of March were very similar, while those for the $12^{\text {th }}$ of March showed more variability (Figure 4). The HPLC pigment composition did not show strong variations among the sampled points, with communities most probably dominated by haptophytes, chlorophytes, and maybe diatoms, and in a few cases cyanophytes. This also would suggest the presence of small cells. Again, the ratios of particular pigments to chl- $a$ used as indices to identify different phytoplankton groups showed a more diverse composition in the northernmost stations (12 ${ }^{\text {th }}$ of March). These stations are influenced by the mixing of the $\mathrm{BC}$, the MC and the La Plata River, with a consequent mixture of subtropical and subantartic organisms ${ }^{16,17}$. According to the pigment composition and the specific absorption, the phytoplankton community was more homogeneous in the southern stations, collected during March $10^{\text {th }}$ and $11^{\text {th }}$, in each case separately.

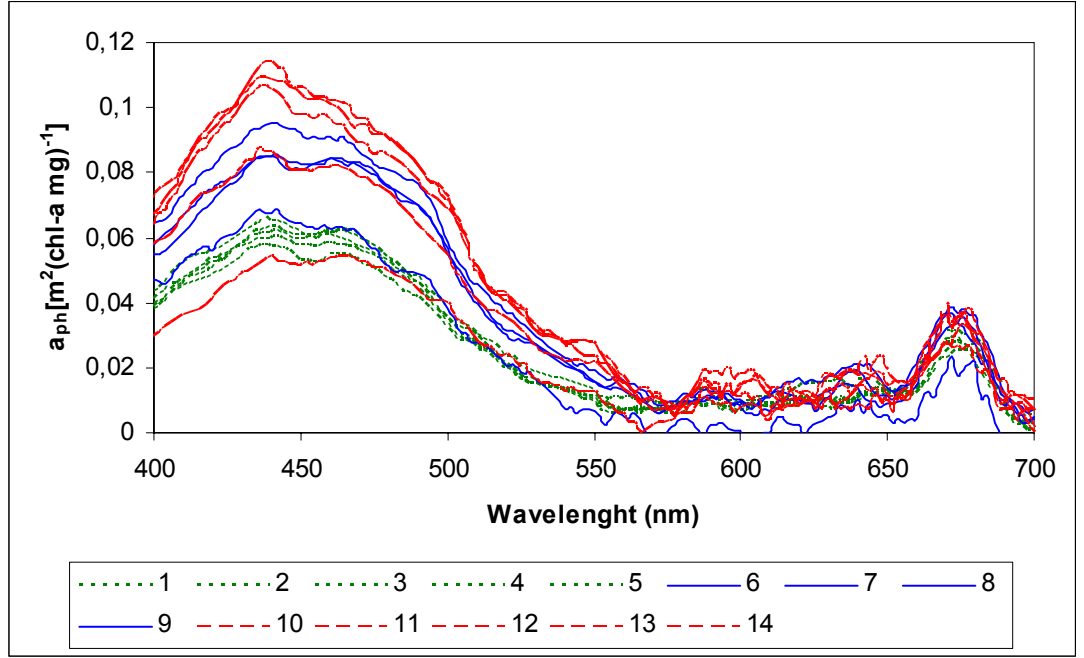

Fig. 4. $a_{p h}^{*}(440)$ for the analyzed stations. Dotted green, solid blue, and dashed red refer to the consecutive stations realized on days 10th, 11th, and 12th of March, respectively.

When analyzed day by day, the performance of all the different algorithms used to estimate $\mathrm{a}_{\mathrm{ph}}(440)$ was good for the first two days separately ( $\mathrm{r}^{2} 0.60$ to 0.96$)$ and extremely poor for the $12^{\text {th }}$ of March $\left(\mathrm{r}^{2}<0.1\right)$. This analysis, although weak (taking no more than 5 points at the time), shows that for similar phytoplankton composition all algorithms perform well. Table 3 presents the overall $\mathrm{a}_{\mathrm{ph}}(440)$ performances. When considering both $\mathrm{r}^{2}$ and error parameters, the CARDER algorithm yielded slightly better results than the QAA algorithm, while the GSM01 had a much weaker 
performance. The overall performances of the analyzed algorithms may have been influenced by a combination of factors, including variations in the contribution of absorption by different optical components in the water, and taking into account that absorption by CDOM was not correlated to absorption by phytoplankton. Sharp spatial gradients of the in situ optical properties difficult the estimation of satellite chl- $a$ by any of the algorithms.

The in situ $\mathrm{a}_{\text {cdom }}(440)$ varied from 0.022 to $0.145 \mathrm{~m}^{-1}$, having a mean value of $0.057( \pm 0.034) \mathrm{m}^{-1}$, thus characterizing the stations as CDOM rich waters with high variability. The northernmost stations showed the highest mean $\mathrm{a}_{\text {cdom }}(440)$ and presented the greatest standard deviation $\left(0.069 \pm 0.046 \mathrm{~m}^{-1}\right)$, probably due to the proximity of the La Plata River discharge. The mid stations also had high $\mathrm{a}_{\text {cdom }}(440)(0.061 \pm 0.032)$, but for the southernmost stations, the values were lower and with less variability $\left(0.041 \pm 0.019 \mathrm{~m}^{-1}\right)$. It is possible to note a South-North gradient of increasing $\mathrm{a}_{\text {cdom }}(440)$ means and standard deviations, indicating that the waters tend to become more complex as they get closer to more intense mixing zones (Figure 5).

In respect to the SeaWiFS estimation of $\mathrm{a}_{\text {cdom }}(440)$, all algorithms in general yielded underestimated values. Although the comparisons show considerable scatter between SeaWiFS and in situ sampled points, the rmse-L values were not high (Table 3). In high absorbing regions as the BMC, the CDOM signal is usually strong enough to ensure that this measurement is much more accurate than in typical open ocean waters ${ }^{18}$. Since the BMC is characterized by CDOM rich waters, the SeaWiFS retrieved values can be considered reasonably accurate.

Table 3. Overall SeaWiFS performance for the absorption coefficients, with respect to spectro-photometer data.

\begin{tabular}{ccccccc}
\hline Absorption & rmse-L & RDP & ADP & $\mathbf{r}^{2}$ & Slope & Intercept \\
\hline $\mathrm{a}_{\mathrm{ph}}(440)$ CARDER & 0.56 & -25.76 & 27.51 & 0.61 & 0.48 & 0.01 \\
$\mathrm{a}_{\mathrm{ph}}(440)$ GSM01 & 1.04 & -46.45 & 46.45 & 0.42 & 0.37 & 0.01 \\
$\mathrm{a}_{\mathrm{ph}}(440)$ QAA & 0.90 & -37.11 & 39.35 & 0.63 & 0.78 & -0.01 \\
$\mathrm{a}_{\text {cdom }}(440)$ CARDER & 1.28 & -45.99 & 47.97 & 0.10 & 0.06 & 0.02 \\
$\mathrm{a}_{\text {cdom }}(440)$ GSM01 & 1.04 & -33.23 & 38.90 & 0.05 & 1.12 & 0.02 \\
$\mathrm{a}_{\text {cdom }}(440)$ QAA & 0.87 & -19.71 & 36.71 & 0.09 & 0.09 & 0.02 \\
\hline
\end{tabular}

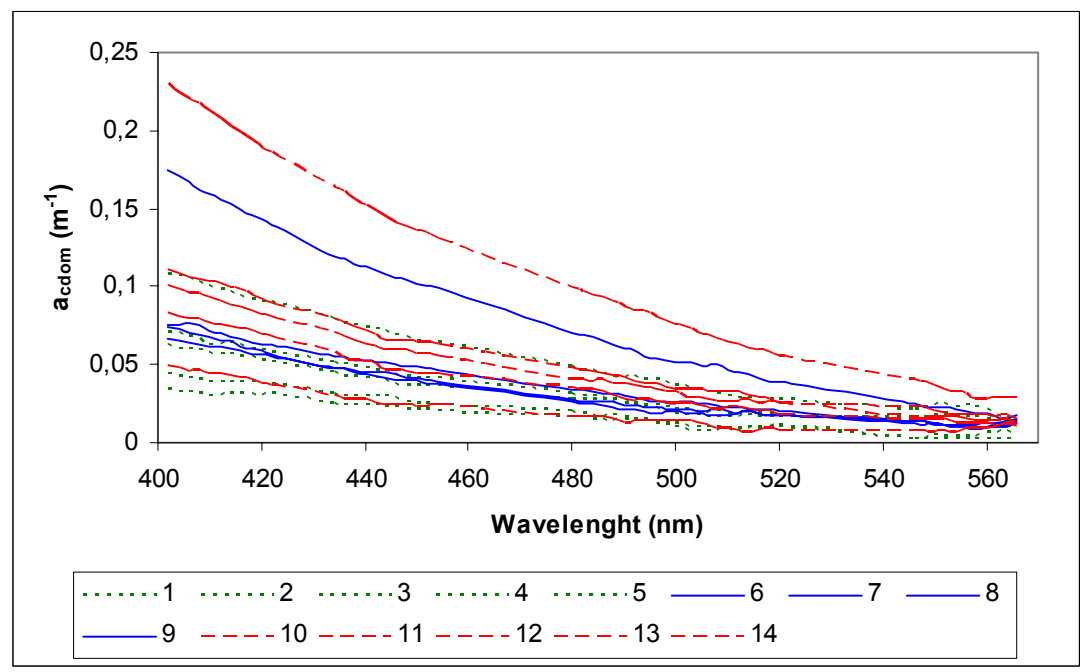

Fig. 5. CDOM absorption for the analyzed stations. Dotted green, solid blue, and dashed red refer to the consecutive stations realized on days $10^{\text {th }}, 11^{\text {th }}$, and $12^{\text {th }}$ of March, respectively.

Regarding the SeaWiFS chl- $a$ estimation, all algorithms showed reasonable coefficients of determination, between 0.45 0.50 (Figure 6, Table 4). The low in situ chl- $a$ values at the northernmost stations were underestimated by both GSM01 and CARDER semi-analytical algorithms. These underestimations can be associated with the heterogeneity of 
phytoplankton communities during the third sampling day, as shown by the HPLC pigment composition analysis. The weak performances on estimation of $\mathrm{a}_{\mathrm{ph}}(440)$ due to community heterogeneity could have lead to imprecision on the chl$a$ estimates, since these algorithms are based on the modeling of the optical properties of seawater. On the other hand, for the stations realized further south on the second day, when the communities were more homogeneous, the estimates had a better fit, presenting both underestimations and overestimations of chlorophyll concentrations, but with smaller errors. The SeaWiFS OC4 and the Simbad OC2 algorithms overestimated lower chl- $a$ values and underestimated higher concentrations. The empirical algorithms have a tendency to overestimate chl- $a$ at CDOM rich Case II waters ${ }^{9}$, as in the northernmost stations. The CARDER algorithm underestimated the lower chl- $a$ values but well estimated the higher concentrations. Finally, GSM01 algorithm underestimated almost all the chl- $a$ values. In general, it is difficult to draw definite conclusions with only a few match-ups as in this work.
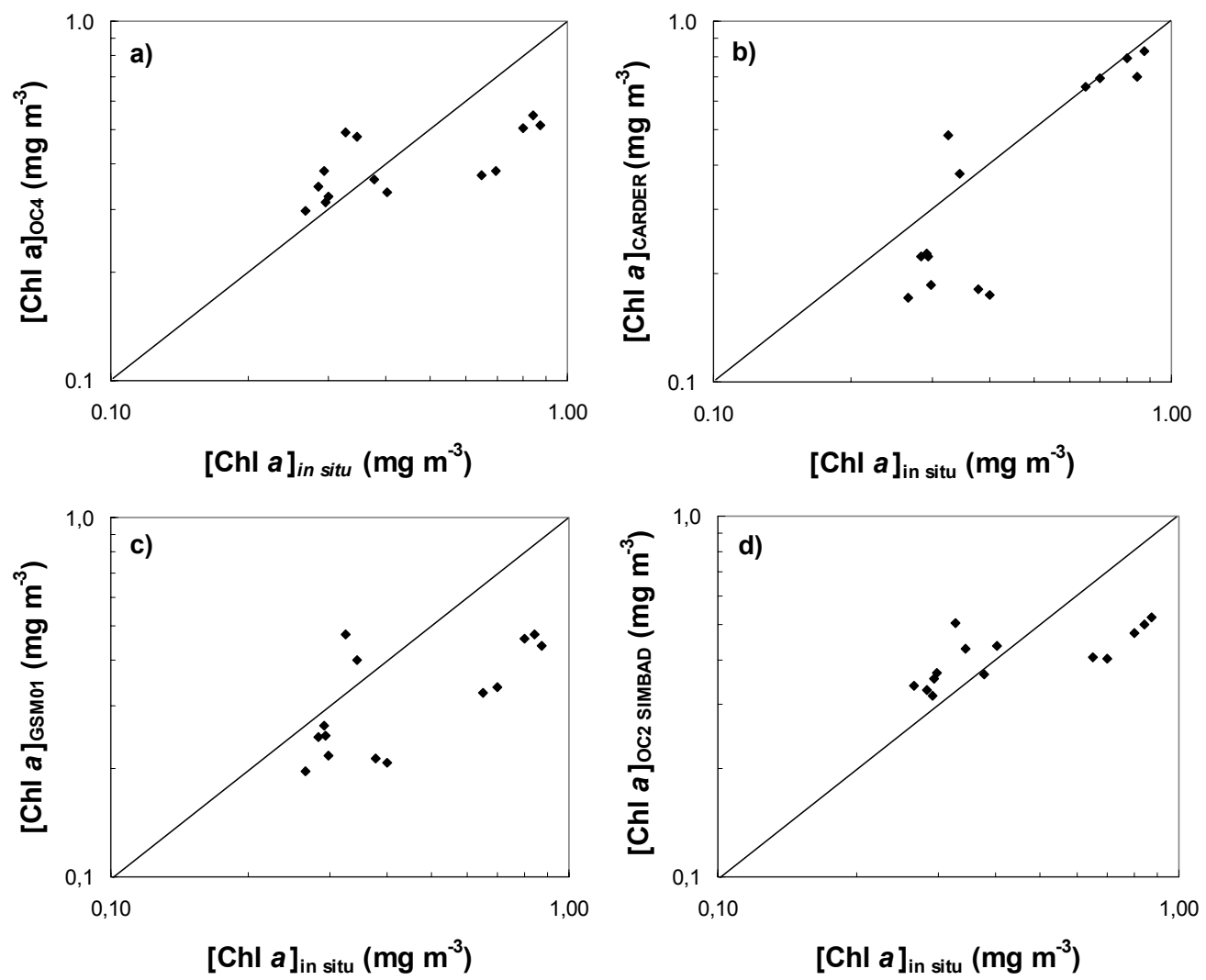

Fig. 6. Plots of chl- $a$ estimated by algorithms applied on orbital (a, b, and c) and SIMBAD (d) data in situ chl- $a$ determined by HLPC.

Garcia et al. ${ }^{12}$ analyzed a more robust bio-optical data set applying empirical and semi-analytical algorithms for chl- $a$ estimates in the Southwestern Atlantic coastal region. Those authors concluded that the use of semi-analytical models does not improve significantly the accuracy of chlorophyll retrievals in coastal areas when not properly tuned with regional inherent optical properties measurements. 
Table 4. Performance of empirical and semi-analytical algorithms, with respect to in situ HPLC chl- $a$.

\begin{tabular}{ccccccc}
\hline Algorithm & rmse-L & RDP & ADP & $\mathbf{r}^{2}$ & Slope & Intercept \\
\hline OC4 & 0.52 & -3.73 & 27.93 & 0.45 & 0.245 & 0.286 \\
CARDER & 0.55 & -15.45 & 23.81 & 0.86 & 1.029 & -0.073 \\
GSM01 & 0.70 & -25.88 & 34.64 & 0.45 & 0.311 & 0.171 \\
OC2V4 $_{\text {SIMBAD }}$ & 0.15 & 0.51 & -1.60 & 0.50 & 0.210 & 0.310 \\
\hline
\end{tabular}

\section{FINAL CONSIDERATIONS}

In this work, in situ bio-optical data and SeaWiFS-derived products from the Southwestern Atlantic were statistically compared and analyzed. Based on the relative contribution of the specific absorption coefficients, $\mathrm{a}_{\mathrm{ph}}(440), \mathrm{a}_{\mathrm{cdom}}(440)$, and $\mathrm{a}_{\mathrm{s}}(440)$, to the total absorption, the sampled waters in the BMC zone were classified as Case II with a mixture of CDOM and phytoplankton.

In general, the SeaWiFS-derived and SIMBAD measured AOT values were low, but with a good agreement between the two types of estimates within SIMBAD uncertainty errors. The SeaWiFS-derived $\mathrm{R}_{\mathrm{RS}}$ was systematically underestimated maybe due to some overestimation of AOT, but still with good fits.

The values of $a_{p h}^{*}(440)$ were high indicating the presence of small size cells with a low packaging effect. The HPLC pigment composition did not show strong variations among the sampled points, with communities most probably dominated by haptophytes, chlorophytes, and maybe diatoms, and in a few cases cyanophytes. The analyzes of the different algorithms used to estimate $\mathrm{a}_{\mathrm{ph}}(440)$ showed that for similar phytoplankton composition all algorithms performed well.

The analyzes of the in situ $\mathrm{a}_{\text {cdom }}(440)$ values characterized the sampling stations as CDOM rich waters. In high absorbing regions as the $\mathrm{BMC}$, the CDOM signal is usually strong enough to ensure that this measurement is much more accurate than in typical open ocean waters.

Regarding the SeaWiFS chl- $a$ estimation, all algorithms showed reasonable performances. The empirical algorithms overestimated lower chl- $a$ values and underestimated higher concentrations. These algorithms have a tendency to overestimate chl- $a$ at CDOM rich Case II waters, as observed in the study area, particularly at the northernmost sampled stations. The GSM01 semi-analytical algorithm underestimated almost all the chl- $a$ values, while CARDER underestimated only the lower concentrations. In general, it is difficult to draw definite conclusions with only a few match-ups as in this work. But other authors already concluded that the use of semi-analytical models does not improve significantly the accuracy of chlorophyll retrievals in coastal areas of the BMC when not properly tuned with regional inherent optical properties measurements.

\section{ACKNOWLEDGMENTS}

The authors gratefully acknowledge the participants of the NF-POGO Ocean-Color Training Group for all contributions. Funding for this work was provided by the Nippon Foundation, the Partnership for the Observation of the Global Ocean (POGO), the National Aeronautics and Space Administration (NASA), the National Space Research Institute (INPE), and the Oceanographic Institute of the University of Sao Paulo (IOUSP). F.M.R. also thanks the Brazilian National Research Council for the financial support regarding the Institutional Capacity Program. 


\section{REFERENCES}

1. A. L. Gordon, "Brazil-Malvinas Confluence-1984". Deep-Sea Res., 36, 359-384 (1989).

2. Peterson,R.G. and Stramma.L. "Upper-level circulation in the South Atlantic Ocean". Prog. Oceanogr., 26,1-73 (1991).

3. P. Y. Deschamps, B. Fougnie, R. Frouin, P. Lecomte, C. Verwaerde, "SIMBAD: a field radiometer for satellite ocean-color validation". Applied Optics, 43 (20), 4055-4069 (2004).

4. B. G. Mitchell, M. Kahru, J. Wieland, M. Stramska, Determination of spectral absorption coefficients of particles, dissolved material and phytoplankton for discrete water samples. In: Fargion, G. S. and Mueller, J. L. (Eds.). Ocean Optics Protocols for Satellite Ocean Color Sensor Validation, Revision 2. NASA/TM-2000- 209966. NASA Goddard Space Flight Center, Greenbelt, Maryland: 125-153 (2000).

5. R. R. Bidigare, and C. Trees, HPLC Phytoplankton Pigments: Sampling, Laboratory Methods, and Guality Assurance Procedures. In: Fargion, G. S. and Mueller, J. L. (Eds.). Ocean Optics Protocols for Satellite Ocean Color Sensor Validation, Revision 2. NASA/TM-2000-209966, NASA, Goddard Soace Flight Center, Greenbelt, Maryland, 154-169 (2000).

6. L. Prieur, S. Sathyendranath, "An Optical Classification of Coastal and Oceanic Waters Based on the Specific Spectral Absorption Curves of Phytoplankton Pigments, Dissolved Organic Matter, and Other Particulate Materials". Limnology and Oceanography, 26 (4), 671-689 (1981).

7. J. E. O'Reilly, S. Maritorena, B. G. Mitchell, D. A. Siegel, K. L. Carder, S. A. Garver, M. Kahru, C. McClain, "Ocean color chlorophyll algorithms for SeaWiFS". J. Geophys. Res., 103(C11), 24937-24954 (1998).

8. K. L. Carder, F. R. Chen, Z. P. Lee, S. K. Hawes, K. Kamykowski, "Semianalytic Moderate-Resolution Imaging Spectrometer algorithms for chlorophyll- $a$ and absorption with bio-optical domains based on nitrate-depletion temperatures". Journal of Geophysical Research, 104, 5403-5421 (1999).

9. K. L. Carder, F. R. Chen, J. P. Cannizzaro, J. W. Campbell, B. G. Mitchell, "Performance of the MODIS semianalytical ocean color algorithm for chlorophyll-a". Advances in Space Research, 33, 1152-1159 (2004).

10. S. Maritorena, D. A. Siegel, A. R. Peterson, "Optimization of a semi-analytical ocean color model for global-scale applications". Applied Optics, 41 (15), 2705-2714 (2002).

11. A. P. Lee, K. L. Carder, R. A. Arnone, "Deriving inherent optical properties from water color: a multiband quasianalytical algorithm for optically deep waters". Applied Optics, 41 (27), 5755-5772 (2002).

12. V. M. T. Garcia, S. Signorini, C. A. E. Garcia, C. R. McClain, "Empirical and semi-analytical chlorophyll algorithms in the southwestern Atlantic coastal region $\left(25-40^{\circ} \mathrm{S}\right.$ and $\left.60-45^{\circ} \mathrm{W}\right)$ ". International Journal of Remote Sensing, 27 (8), 1539-1562 (2006).

13. S. I. Romero, A. R. Piola, M. Charo, C. A. E. Garcia, "Chlorophyll-a variability off Patagonia based on SeaWiFS data". Journal of Geophysical Research, 111 (C5), C05021 (2006).

14. M. Saraceno, C. Provost, A. R. Piola, "On the relationship between satellite-retrieved surface temperature fronts and chlorophyll a in the western South Atlantic". Journal of Geophysical Research, 110, C11016 (2005).

15. S. R. Signorini, V. M. T. Garcia, A. R. Piola, C. A. E. Garcia, M. M. Mata, C. R. McClain, "Seasonal and interannual variability of calcite in the vicinity of the Patagonian shelf break $\left(38^{\circ} \mathrm{S}-52^{\circ} \mathrm{S}\right)$ ". Geophysical research letters, 33, L16610 (2006).

16. G. E. R. Deacon, "Physical and biological zonation in the Southern Ocean". Deep-Sea Research, 29, 1-15 (1982).

17. A. M. Gayoso, G. P. Podestá, "Surface hydrography and phytoplankton of the Brazil-Malvinas currents confluence". Journal of Plankton Research, 18 (6), 941-951 (1996).

18. M. Darecki and D. Stramski. "An evaluation of MODIS and SeaWiFS bio-optical algorithms in the Baltic Sea". Remote Sensing of Environment., 89 (3), 326-350 (2004). 